\title{
GREEN HUMAN RESOURCE MANAGEMENT: AN EMPIRICAL STUDY OF INDIA
}

\author{
Mamta Arora, Arpita Kaul*
}

University of Delhi, India

Purpose: The broad over-arching goals of this work were to study the existing constituents of green human resource management (HRM), to understand the green HRM practices being followed by different companies in India (belonging to certain sectors) and to compare the different sectors in terms of adoption of green HRM. Methodology: A questionnaire was meticulously prepared by the authors to collect the data for this study and was sent to various Indian companies belonging to four sectors: IT/IT services, banking/finance, consultancy and engineering/ technology. The questionnaire included a carefully selected collection of questions to gain rich insights into different aspects of green HRM implementation. Findings: most of the companies included in this study are following green HRM (though to varying extents). Green recruitment, green training and development \& green safety and health management are the most prominent green HRM functions while green performance appraisal is the least popular green HRM function among these organizations. The IT/IT services sector is most actively using green HRM practices while the banking/finance sector is the most reluctant to adopt green HRM. Practical Implications: a rigorous structure for companies to implement green HRM is provided.

Keywords: environment; green HRM; questionnaire

Green human resource management (HRM) has gained significance over the past few decades as the world has realized that climate change is going to have a devastating impact on all forms of life if left unchecked and hence there is a dire need to adopt environment-friendly practices in all domains. What is green HRM? How do you define the term? The various definitions of Green HRM proposed by the authors of different journal articles in this field across the globe are compiled in Table 1.

Table 1 Definitions of green HRM

\begin{tabular}{|c|c|}
\hline Author(s) & Definition \\
\hline $\begin{array}{l}\text { Renwick, Redman and } \\
\text { Maguire, } 2012\end{array}$ & $\begin{array}{l}\text { The integration of corporate environmental management into } \\
\text { human resource management is termed as Green HRM }\end{array}$ \\
\hline Mandip, 2012 & $\begin{array}{l}\text { Green HRM refers to the use of every employee touch point/ } \\
\text { interface to promote sustainable practices and increase } \\
\text { employee awareness and commitments on the issues of } \\
\text { sustainability. }\end{array}$ \\
\hline $\begin{array}{l}\text { Martha and Adhikari, } \\
2013\end{array}$ & $\begin{array}{c}\text { Green HRM is the use of HRM policies to promote the sustainable } \\
\text { use of resources within organizations and more generally } \\
\text { promotes the causes of environmental sustainability }\end{array}$ \\
\hline Mathapati, 2013 & $\begin{array}{l}\text { Green HRM is directly responsible for creating a green workforce } \\
\text { that understands, appreciates and practises green initiatives and } \\
\text { maintains its green objectives all throughout the HRM process } \\
\text { of recruiting, hiring, training, compensating, developing and } \\
\text { advancing the firm's human capital }\end{array}$ \\
\hline Opatha and Anton, 2014 & $\begin{array}{l}\text { It refers to the policies, practices and systems that make } \\
\text { employees of the organization green for the benefit of the } \\
\text { individual, the society, the natural environment and the business }\end{array}$ \\
\hline
\end{tabular}

The various functions of green HRM are green recruitment, green selection, green induction, green training and development, green compensation, green performance appraisal, green discipline management etc.

\section{Green recruitment}

The various aspects involved in green recruitment are:

1. Employer branding the organization as environment-friendly so that prospective candidates who apply for the job are the ones who are genuinely concerned about the environment.
2. Inviting candidates who have a genuine concern for the environment because an organization can flourish as an environment-friendly entity only if it employs people who sincerely care about the environment.

3. Recruiting through online portals rather than newspaper advertisements as that saves paper and is a move towards going green.

Green recruitment can be defined as the process of hiring individuals with knowledge, skills, approaches and behaviours that identify with environmental management systems within an organization. "Recruitment practices can support effective environmental management by making sure that new entrants are familiar with an organization's environmental culture and are capable of maintaining its environmental values" (Wehermeyer, 1996). Those candidates who seriously care about environmental matters would be more comfortable working in organizations that lead from the front in terms of environmental issues (all other things being the same).

Table 2 Green recruitment

\begin{tabular}{|c|c|}
\hline Author(s) & Practices \\
\hline Wehermeyer, 1996 & $\begin{array}{l}\text { Incorporating a number of environment-protection related tasks, } \\
\text { duties and responsibilities in each job }\end{array}$ \\
\hline Opatha and Anton, 2014 & Including environmental criteria in recruitment messages \\
\hline Opatha and Anton, 2014 & $\begin{array}{l}\text { Communicating the employer's concern about greening through } \\
\text { recruitment efforts }\end{array}$ \\
\hline
\end{tabular}

\section{Green selection}

Recruitment aims at inviting candidates to apply for a job while selection means choosing the best candidates from the pool of applicants. Green selection involves making the environment a criterion in the selection process, asking questions related to the environment in order to judge the knowledge and interest of the candidates with respect to environmental matters, conducting telephonic or web-based interviews to minimize travelrelated impact on the environment etc. 
Table 3 Green selection

\begin{tabular}{|l|c|}
\hline Author(s) & \multicolumn{1}{c|}{ Practices } \\
\hline $\begin{array}{l}\text { Renwick, Redman and } \\
\text { Maguire, 2012 }\end{array}$ & $\begin{array}{r}\text { Considering environmental concern and interest of the } \\
\text { candidates as selection criteria." }\end{array}$ \\
\hline $\begin{array}{l}\text { Crosbie and Knight, } \\
\text { 1995; Wehermeyer, 1996; } \\
\text { North, 1997; (Revill, 2000 }\end{array}$ & $\begin{array}{r}\text { Asking environment-related questions when interviewing } \\
\text { candidates or evaluating them for selection." }\end{array}$ \\
\hline Opatha and Anton, 2014 & $\begin{array}{r}\text { Selecting applicants who are sufficiently aware of greening to } \\
\text { fill job vacancies." }\end{array}$ \\
\hline Opatha and Anton, 2014 & $\begin{array}{r}\text { Selecting applicants who have been engaging in greening as } \\
\text { consumers in their private lives }\end{array}$ \\
\hline
\end{tabular}

\section{Green induction}

Induction means employees' orientation to the culture of the company. Green induction comprises of general and specific green induction. General green induction means introducing employees to the green policies of the company and specific green induction is specific to the job.

\section{Table 4 Green induction}

\begin{tabular}{l|l}
\hline Author(s) & \multicolumn{1}{c}{ Practices } \\
\hline $\begin{array}{l}\text { Crosbie and Knight, 1995; } \\
\text { Wehermeyer, 1996; North, } \\
\text { 1997; Revill, 2000; Renwick, } \\
\text { Redman and Maguire, 2012; } \\
\begin{array}{l}\text { Renwick, Redman and } \\
\text { Maguire, 2013 }\end{array}\end{array}$ \\
\hline $\begin{array}{l}\text { Crosbie and Knight, 1995; } \\
\text { Wehermeyer, 1996; North, } \\
\text { 1997; Revill, 2000; Renwick } \\
\text { et al., 2008; Renwick, } \\
\text { Redman and Maguire, 2012 }\end{array}$ & $\begin{array}{l}\text { Providing general Green Induction } \\
\text { Providing job-specific Green Induction }\end{array}$ \\
\hline $\begin{array}{l}\text { Opatha and Anton, 2014 } \\
\text { the organization and encouraging them to engage in green } \\
\text { interpersonal citizenship behaviour }\end{array}$ \\
\hline $\begin{array}{l}\text { Opatha and Anton, 2014 } \\
\text { Developing induction programs showing green citizenship } \\
\text { behaviour of current employees }\end{array}$
\end{tabular}

\section{Green training and development}

Green training and development means enhancing the knowledge and skills of employees in the domain of environment-management. With increasing competition, it has become even more important for companies to invent new products, processes and procedures which promote greening. Green training and development plays a pivotal role in helping organizations accomplish this objective.

Table 5 Green training and development

\begin{tabular}{|l|c|}
\hline Author(s) & \multicolumn{1}{c|}{ Practices } \\
\hline Cook and Seith, 1992 & $\begin{array}{c}\text { Providing environmental training to the members of the } \\
\text { organization (employees and managers) to develop the required } \\
\text { skills and knowledge }\end{array}$ \\
\hline $\begin{array}{l}\text { Renwick, Redman } \\
\text { and Maguire, 2012; } \\
\text { Jackson et al., 2011 }\end{array}$ & $\begin{array}{c}\text { Providing training regarding environment-friendly best practices } \\
\text { (e.g. reducing long-distance business travel and recycling) }\end{array}$ \\
\hline North, 1997 & $\begin{array}{c}\text { Providing environmental awareness training to create } \\
\text { environmental awareness amongst the workforce }\end{array}$ \\
\hline North, 1997 & $\begin{array}{c}\text { Providing environmental education to the workforce } \\
\text { Providing training to the staff to produce green analysis of } \\
\text { workspace }\end{array}$ \\
\hline $\begin{array}{l}\text { Renwick, Redman } \\
\text { and Maguire, 2012 }\end{array}$ &
\end{tabular}

\section{Continuation of table 5}

\begin{tabular}{|l|c|}
\hline $\begin{array}{l}\text { Author(s) } \\
\text { Renwick, Redman and } \\
\text { Maguire, 2012 }\end{array}$ & $\begin{array}{c}\text { Practices } \\
\text { Opplying job rotation to train green managers of the future }\end{array}$ \\
\hline $\begin{array}{c}\text { Imparting the right knowledge and skills about greening (to } \\
\text { each employee through a training program exclusively designed } \\
\text { for greening) }\end{array}$ & $\begin{array}{c}\text { Conducting training needs analysis to identify green training } \\
\text { needs of employees. }\end{array}$ \\
\hline $\begin{array}{c}\text { Analysing and identifying environmental training needs } \\
\text { of employees to make them more concerned about the } \\
\text { environment. }\end{array}$ \\
$\begin{array}{r}\text { Conducting a serious and systematic training program which } \\
\text { is given to each employee for the purpose of providing } \\
\text { relevant information and guidelines related to environment- } \\
\text { management. }\end{array}$ \\
$\begin{array}{r}\text { Providing opportunities to everybody to be trained on } \\
\text { environmental management aspects }\end{array}$
\end{tabular}

\section{Green performance appraisal}

Green performance appraisal means setting up green standards and evaluating the green performance of employees.

Table 6 Green performance evaluation

\begin{tabular}{|c|c|}
\hline Author(s) & Practices \\
\hline $\begin{array}{l}\text { Wells et al., 1993; } \\
\text { Carpenter, 1994; } \\
\text { Schwalm, 1994; Milliman } \\
\text { and Clair, 1996) }\end{array}$ & $\begin{array}{l}\text { Establishing environmental management information system } \\
\text { (EMIS) and environmental audits }\end{array}$ \\
\hline Wehermeyer, 1996) & $\begin{array}{c}\text { Incorporating corporate environmental management objectives } \\
\text { and targets in the performance evaluation system of the } \\
\text { organization }\end{array}$ \\
\hline $\begin{array}{l}\text { Milliman and Clair, 1996; } \\
\text { Renwick et al., 2008; } \\
\text { Renwick et al., } 2013\end{array}$ & Installing company-wide environmental performance standards \\
\hline $\begin{array}{l}\text { Renwick et al., 2008; } \\
\text { Renwick et al., } 2013 \\
\end{array}$ & $\begin{array}{l}\text { Integrating green criteria in appraisals or evaluating employees' } \\
\text { job performance according to environment-related criteria }\end{array}$ \\
\hline Opatha, 2014 & $\begin{array}{l}\text { Including a separate component for progress on greening in the } \\
\text { performance feedback interview }\end{array}$ \\
\hline $\begin{array}{l}\text { Renwick et al., 2008; } \\
\text { Renwick et al., } 2013\end{array}$ & $\begin{array}{l}\text { Setting green targets, goals and responsibilities. } \\
\text { Providing regular feedback to the employees or teams to } \\
\text { achieve environmental goals or improve their environmental } \\
\text { performance. } \\
\text { Formally evaluating all employees' green job performance (as } \\
\text { far as possible) }\end{array}$ \\
\hline
\end{tabular}

\section{Green reward management}

Table 7 Green reward management

\begin{tabular}{l|c|}
\hline Author(s) & \multicolumn{1}{c}{ Practices } \\
\hline $\begin{array}{l}\text { Crosbie and Knight, 1995; } \\
\text { Renwick et al., 2008 and } \\
2013\end{array}$ & $\begin{array}{c}\text { Rewarding employee environmental performance (good/ } \\
\text { excellent and extraordinary) }\end{array}$ \\
\hline $\begin{array}{l}\text { Crosbie and Knight, 1995; } \\
\text { Renwick et al., 2008 and } \\
\text { 2013; 0patha, 2013 }\end{array}$ & $\begin{array}{c}\text { Financially rewarding employees for good environmental } \\
\text { performance }\end{array}$ \\
\hline $\begin{array}{l}\text { Whitenight, 1992; Bhushan } \\
\text { and Mackenzie, 1994; } \\
\text { Renwick et al., 2008 and } \\
\text { 2013; 0patha, 2013 }\end{array}$ & $\begin{array}{c}\text { Non-financially rewarding employees for good } \\
\text { environmental performance }\end{array}$ \\
\hline $\begin{array}{l}\text { Bhushan and Mackenzie, } \\
\text { 1994 }\end{array}$ & $\begin{array}{l}\text { Team excellence awards for good environmental } \\
\text { performance }\end{array}$
\end{tabular}




\section{Continuation of table 7}

\begin{tabular}{l|c|}
\hline $\begin{array}{l}\text { Author(s) } \\
\text { Bhushan and Mackenzie, } \\
1994\end{array}$ & $\begin{array}{c}\text { Practices } \\
\text { Introducing rewards for innovative environmental initiatives/ } \\
\text { performance }\end{array}$ \\
\hline $\begin{array}{l}\text { Woods, } 1993 \\
\text { Communicating employee environmental excellence }\end{array}$ \\
\hline $\begin{array}{l}\text { Berry and Randinelli, 1999; } \\
\text { Jackson et al., 2011 }\end{array}$ & $\begin{array}{c}\text { Providing incentives to encourage environment-friendly } \\
\text { activities and behaviours (e.g. recycling and waste } \\
\text { management) }\end{array}$ \\
\hline $\begin{array}{l}\text { Renwick et al., 2008 } \\
\text { and } 2013\end{array}$ & Rewarding employees for acquiring green skills \\
\hline
\end{tabular}

\section{Green safety and health management}

Table 8 Green safety and health management

\begin{tabular}{|c|c|}
\hline Author(s) & \multicolumn{1}{c|}{ Practices } \\
\hline $\begin{array}{c}\text { Ensuring a green workplace for all. Coming up with various } \\
\text { environment-related initiatives to reduce employee stress and } \\
\text { occupational diseases caused by hazardous work conditions } \\
\text { Devising and implementing strategies (e.g. green factory/ } \\
\text { green zone) that can help prevent various health problems and } \\
\text { improve the health and safety of employees }\end{array}$
\end{tabular}

\section{Green employee discipline management}

Table 9 Green employee discipline management

\begin{tabular}{|l|c|}
\hline Author(s) & \multicolumn{1}{c}{ Practices } \\
\hline Renwick et al., 2012 & $\begin{array}{c}\text { Setting penalties for non-compliance with respect to } \\
\text { environmental management targets }\end{array}$ \\
\hline Renwick et al., 2012 & $\begin{array}{c}\text { Setting penalties or dismissing candidates for environmental } \\
\text { management breaches }\end{array}$ \\
\hline $\begin{array}{c}\text { Formulating and publishing rules of conduct related to greening } \\
\text { Developing a progressive disciplinary system to punish } \\
\text { employees who violate the rules of green conduct } \\
\text { Implementing discipline management as a tool to actively } \\
\text { engage employees in environmental protection activities of the } \\
\text { organization } \\
\text { Opatha, 2013 } \\
\begin{array}{c}\text { Establishing a clear set of rules and regulations which highly } \\
\text { encourage (in some sense, compel) employees to be concerned } \\
\text { about environmental protection }\end{array} \\
\text { If an employee violates environmental rules and regulations, } \\
\text { take disciplinary action (warning, fines, suspension etc.) against } \\
\text { him/her }\end{array}$
\end{tabular}

\section{Green employee relations/industrial relations}

Table 10 Green employee relations

\begin{tabular}{|c|c|}
\hline Author(s) & Practices \\
\hline Renwick et al., 2013 & $\begin{array}{l}\text { Providing opportunities to the employees to participate in green } \\
\text { suggestion schemes }\end{array}$ \\
\hline Renwick et al., 2013 & Introducing green whistle-blowing and helplines \\
\hline Renwick et al., 2013 & $\begin{array}{c}\text { Providing training to the union representatives in environmental } \\
\text { management } \\
\text { Joint consultations in solving environmental issues of the } \\
\text { organization } \\
\text { Gain sharing in relation to environmental initiatives or programs } \\
\text { Recognizing union as a key stakeholder in environmental } \\
\text { management } \\
\text { Providing opportunities to the unions to negotiate with } \\
\text { management on green workplace agreement }\end{array}$ \\
\hline
\end{tabular}

\section{Material and methods}

The key objectives of this study were to:

1. Study the existing constituents of green human resource management (HRM).

2. Identify newly emerging components of green HRM.

3. Identify the green HRM practices followed by information technology/information technology (IT) services sector, banking/ finance sector, consultancy sector and engineering/technology sector companies in India.

4. Compare these sectors in terms of implementation of different green HRM practices.

An exploratory research method was used for this purpose. A detailed literature review was carried out and based on the same, a questionnaire of twenty questions was formulated by the authors. The questionnaire was sent to the human resource professionals of certain companies in India. The 16 companies which have formed the basis of this study are listed in Table 11.

Table 11 Sample table

\begin{tabular}{|c|c|}
\hline No. & Name of the company \\
\hline 1. & Tata Consultancy services \\
\hline 2. & HCL Technology Ltd. \\
\hline 3. & Kotak \\
\hline 4. & Times Internet \\
\hline 5. & Mad Influence \\
\hline 6. & American Express \\
\hline 7. & BSES Rajdhani Power Ltd. \\
\hline 8. & Ernst and Young \\
\hline 9. & ONGC \\
\hline 10. & Federal Bank \\
\hline 11. & Reliance Infrastructure Ltd. \\
\hline 12. & MMTC \\
\hline 13. & TAFE \\
\hline 14. & Zyxel Technology India Pvt. Ltd. \\
\hline 15. & IDBI Bank \\
\hline 16. & HeadSpace HR Pvt. Ltd. \\
\hline
\end{tabular}

\section{Results and discussion}

The companies belong to four broad categories i.e. Information technology/ information technology (IT) services, banking/finance, consultancy and engineering/technology as per below details (Table 12).

Table 12 Sector-wise distribution of companies

\begin{tabular}{|c|c|c|}
\hline S. no. & Category & Companies \\
\hline 1. & $\begin{array}{l}\text { information technology/ } \\
\text { information technology (IT) } \\
\text { services }\end{array}$ & $\begin{array}{l}\text { Tata Consultancy services, HCL Technology Ltd., } \\
\text { Times Internet, Zyxel Technology India Pvt. Ltd. }\end{array}$ \\
\hline 2. & banking/finance & Kotak, American Express, Federal Bank, IDBI Bank \\
\hline 3. & consultancy & $\begin{array}{l}\text { Mad Influence, Ernst and Young, HeadSpace HR } \\
\text { Pvt. Ltd. }\end{array}$ \\
\hline 4. & engineering/technology & $\begin{array}{l}\text { BSES Rajdhani Power Ltd., ONGC, Reliance } \\
\text { Infrastructure Ltd., MMTC, TAFE }\end{array}$ \\
\hline
\end{tabular}


Figure 1 visually illustrates the category-wise distribution of companies.

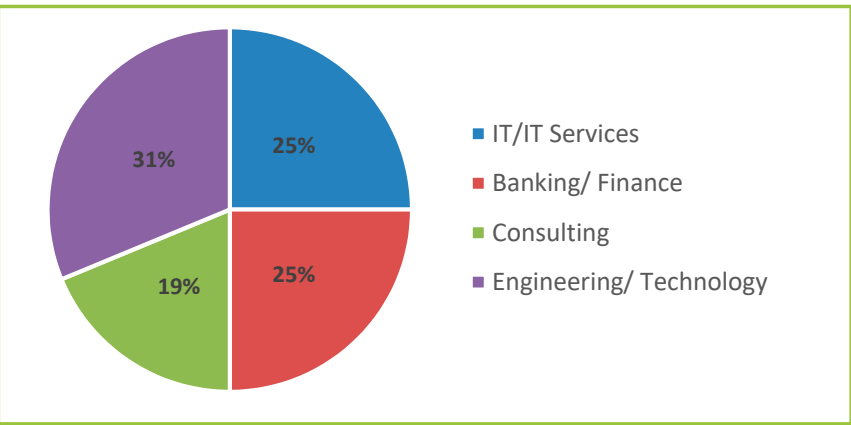

Figure 1 Category-wise distribution of companies

Further analysis was carried out at two levels:

1. Sector-wise analysis:

a) Awareness of the concept of green HRM and implementation of the same.

b) Adoption of green recruitment, green selection, green induction, green training and development ( $T \& D)$, green performance appraisal (PA), green reward management (RM), green safety and health management (SHM), green discipline management (DM) and green employee relations/industrial relations (IR).

2. Overall analysis a cross sectors: Prevalence of different practices associated with the various green HRM functions discussed in (b) above.

Figure 2 depicts the percentage of companies that are aware of green HRM and follow green HRM practices across different sectors. It is evident from figure 2 that the consultancy sector is the only sector in which all the companies are aware of green HRM and follow green HRM practices. In the engineering/technology sector, $80 \%$ of the companies are aware of green HRM and follow green HRM practices. In the banking/finance sector, 75\% of the companies are aware of green HRM and follow it. In the IT/IT services sector, all the companies considered in this study are aware of green HRM but only $75 \%$ follow it.

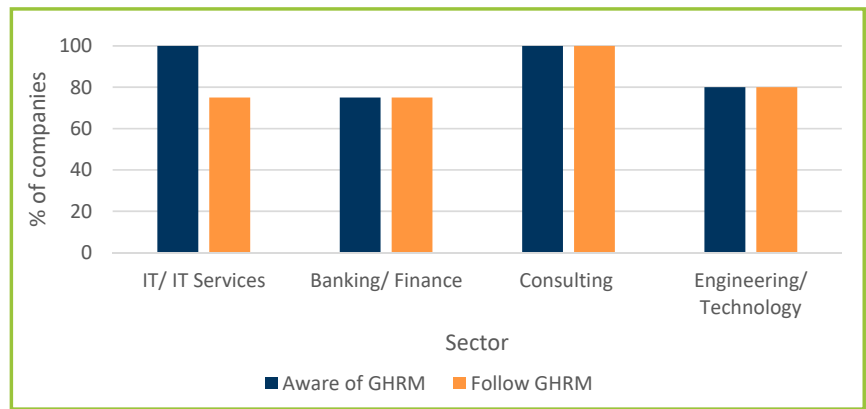

Figure 2 Sector-wise analysis of awareness and implementation of green HRM practices

Figure 3 shows that in the IT/IT services sector, 75\% companies follow green recruitment, green selection and green induction. None of the companies in the banking/finance sector adopt green recruitment, green selection and green Induction. $67 \%$ of the consulting firms included in this study follow green recruitment and green induction and only $33 \%$ follow green selection. In the engineering/technology sector, $80 \%$ of the companies follow green recruitment, $40 \%$ follow green selection and $40 \%$ follow green Induction practices. This implies that except the banking/ finance sector, all the other sectors follow green acquisition practices in some way or the other.

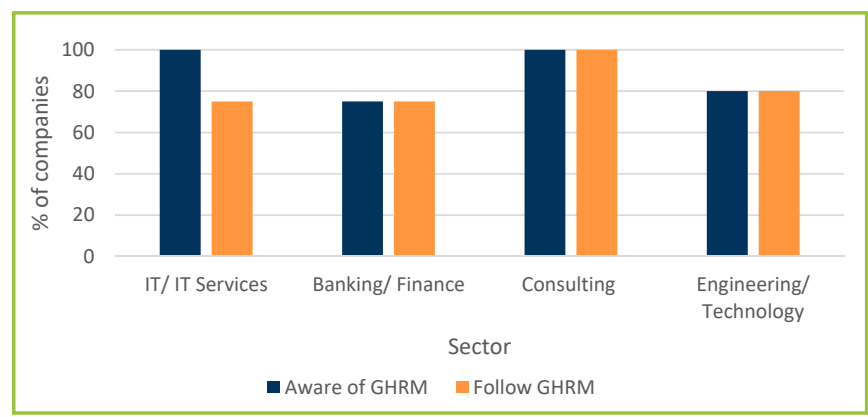

Figure 3 Sector-wise analysis of green acquisition practices

Figure 4 shows that out of the four sectors studied here, the sector which uses green development practices to the maximum extent is the IT/ IT services sector. In terms of the different components of green development practices, green training and development practices are being employed in all sectors (though to varying extents), green performance appraisal practices are not being used at all in the banking/finance, consultancy and engineering/technology sectors while green reward management practices are being used in all the sectors except the consultancy sector.

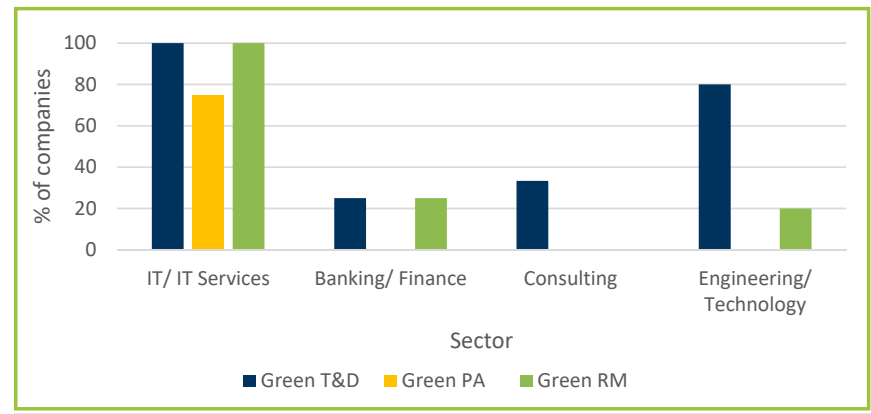

Figure 4 Sector-wise analysis of green development practices

It can be observed from figure 5 that the IT/IT services sector uses green industrial/employee relations practices to the maximum extent. The banking/ finance and consultancy sectors do not employ green discipline management at all.

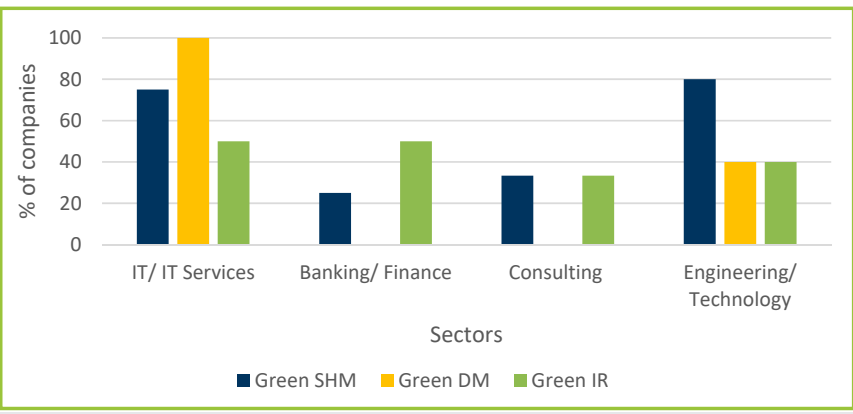

Figure 5 green industrial/employee relations practices

The analysis presented in figures $6-14$ has been performed at an overall level (including all the companies across the four sectors). The percentages in these figures are based on the number of companies that follow green HRM practices corresponding to that category and not the total number of companies included in this study. 
It is evident from figure 6 that out of the companies that follow green recruitment practices, $67 \%$ brand themselves as green organizations, all do e-recruitment and $56 \%$ include environmental criteria in recruitment messages.

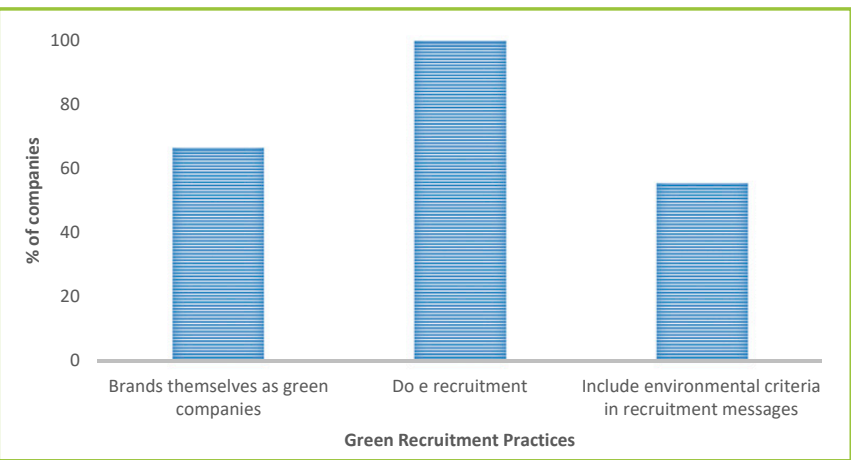

Figure 6 0verall analysis of green recruitment practices

It can be observed from figure 7 that all the companies that use green selection practices ask environment-related questions when interviewing candidates.

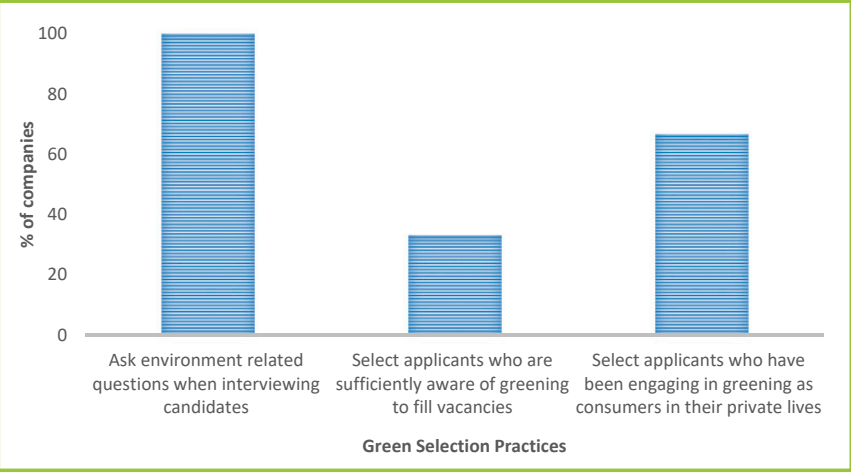

Figure 7 Overall analysis of green selection practices

Figure 8 shows that all the companies that follow green Induction make new employees aware of the greening efforts of the company.

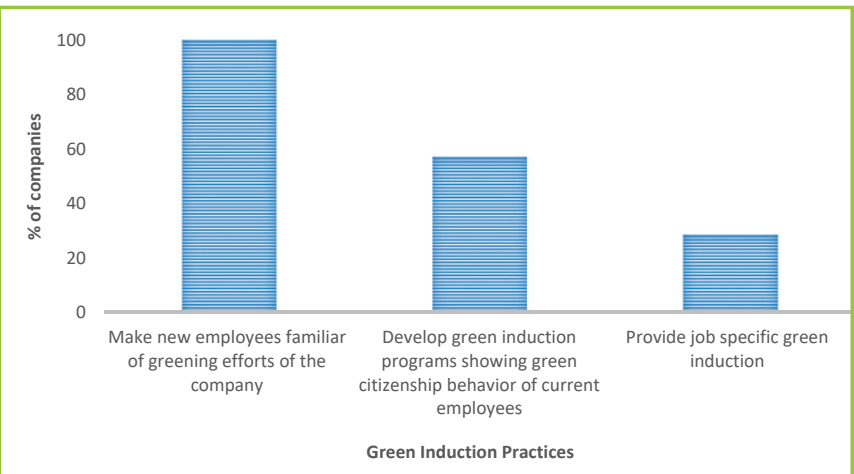

Figure 8 Overall analysis of green induction practices

It can be inferred from figure 9 that out of the companies that follow green training and development practices, $60 \%$ provide environmental training to the employees, $40 \%$ conduct training needs analysis to identify green training needs of the employees and $60 \%$ provide environmental education to the workforce.

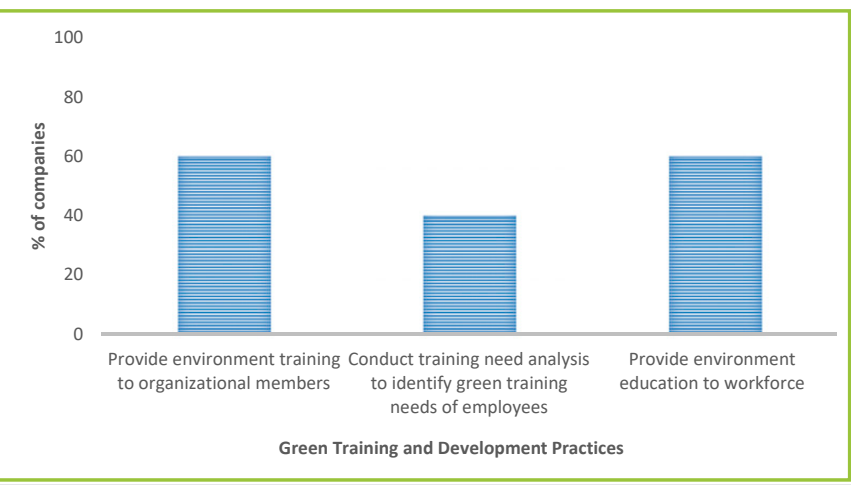

Figure 9 Overall analysis of green training and development practices

As can be seen in Figure 10, all the companies that use green performance appraisal practices formally evaluate all employees' green job performance.

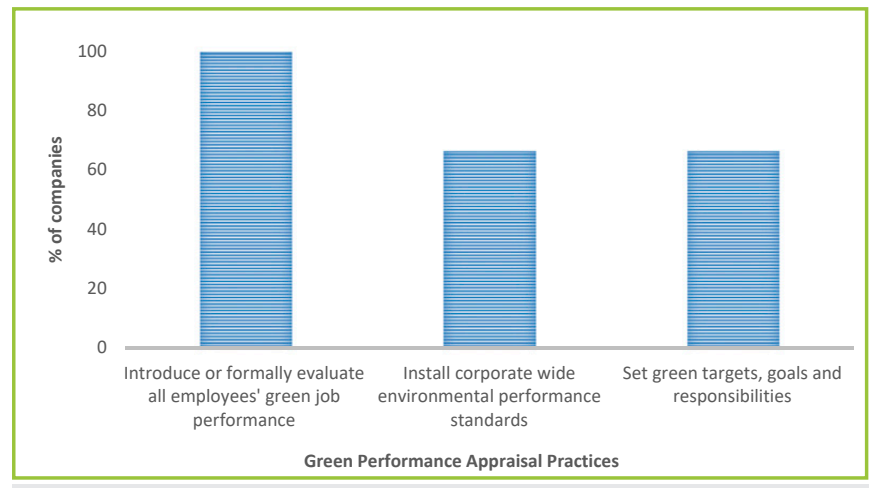

Figure 10 Overall analysis of green performance appraisal practices

Figure 11 shows that out of the companies that implement green reward management practices, $50 \%$ give financial rewards to employees for good environmental performance and $50 \%$ non-financially reward employees for good environmental performance.

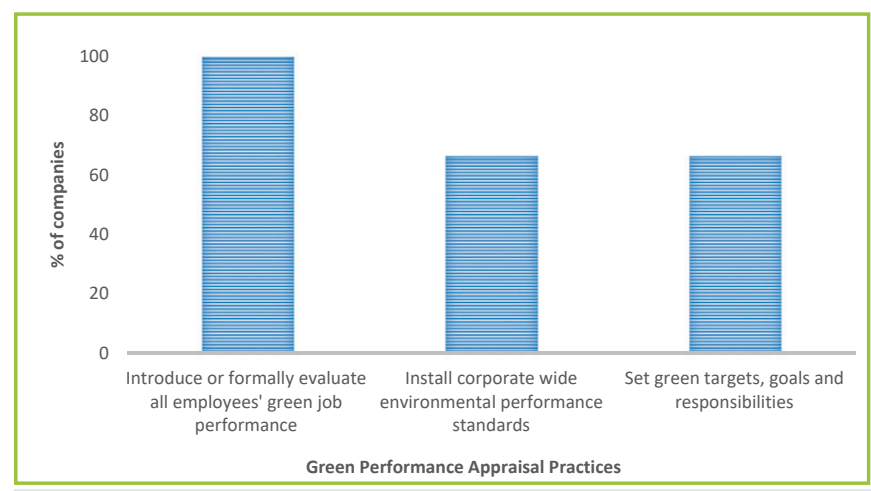

Figure 11 Overall analysis of green reward management practices

Out of the 16 companies included in this study, 9 make use of green safety and health management. All these companies take various initiatives related to the environment to reduce employee stress and occupational diseases caused by hazardous work conditions. $89 \%$ of these organizations make efforts to ensure a green workplace for all. $78 \%$ of these companies devise and implement strategies to create and maintain a safe and healthy work environment for the employees. 


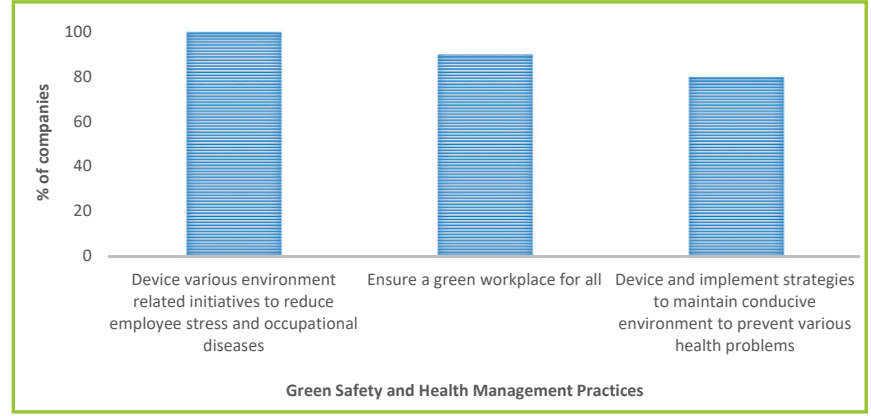

Figure 12 Overall analysis of green safety and health management practices

Figure 13 shows that out of the companies that implement green discipline management practices, $50 \%$ set penalties for non-compliance with respect to environmental management targets, $50 \%$ set penalties or perform dismissals for breaches related to environmental management, $67 \%$ formulate and publish rules of conduct related to greening and $33 \%$ develop a progressive disciplinary system to punish employees who violate the rules of green conduct.

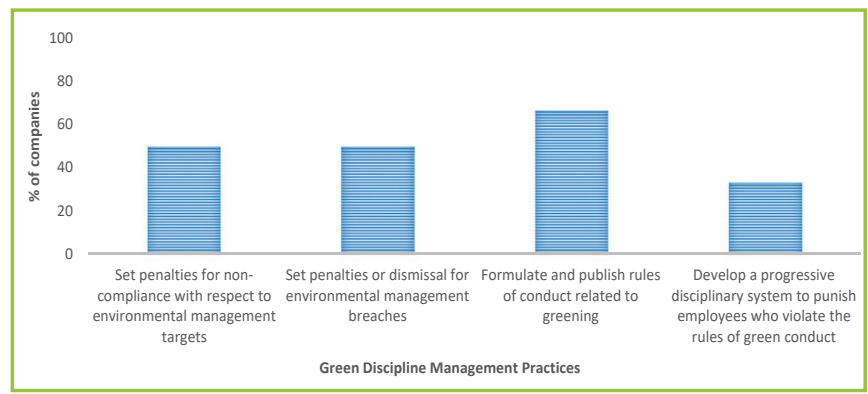

Figure 13 Overall analysis of green discipline management practices

Figure 14 shows that $85 \%$ of the companies (out of the ones that follow green employee relations practices) provide opportunities to the employees to participate in green suggestion schemes, $71 \%$ recognize union as a key stakeholder in the management of the environment and $57 \%$ use joint consultations in solving issues related to the environment.

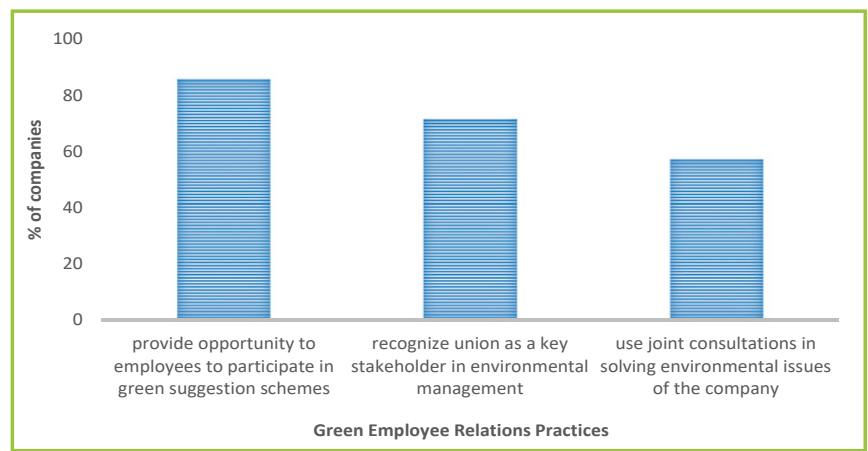

Figure 14 Overall analysis of green employee relations practices

\section{Conclusions}

This work provides an overview of the green human resource management (HRM) practices in 16 Indian companies belonging to 4 sectors: information technology/ information technology (IT) services (4 companies), banking/finance (4 companies), consultancy ( 3 companies) and engineering/technology ( 5 companies). It has been found that all the IT/IT services sector companies and all the consulting firms included in this study are aware of the term green HRM while in the banking/finance sector, only $75 \%$ of the companies are aware of green HRM and follow certain green HRM practices. In the engineering/technology sector, $80 \%$ of the companies are aware of the term green HRM and employ certain green HRM practices.

An interesting observation from this study is that green acquisition practices are not being adopted by any of the banking/finance sector companies included here. Green recruitment, green training and development \& green safety and health management are the most prominent green HRM functions being performed by the organizations surveyed here. Among all the green HRM functions considered here, green performance appraisal is the least popular. Within green recruitment, e-recruitment is the most widely used method.

In the IT/IT services sector, all the companies surveyed in this study follow green training and development, green reward management and green discipline management while in the banking/finance sector, only $25 \%$ of the companies included here do green training and development and green reward management and no company employs green discipline management. In the IT/IT services sector, $75 \%$ of the organizations included in this study carry out green recruitment, green selection, green induction and green performance appraisal while these green HRM practices are not followed in any of the companies belonging to the banking/finance sector surveyed in this work. Thus, these two sectors are poles apart in terms of implementation of green HRM practices and represent the two extremes with respect to the same with the IT/IT services sector being the most enthusiastic in terms of adopting the concept of green HRM and the banking/ finance sector being the most reluctant and sceptical.

It can be concluded that green HRM is a relatively new concept in India but is fast picking up. This study is novel in the Indian context and can be extended to various other sectors like energy, travel and tourism, telecommunication and biotechnology. Industry-specific studies on green HRM can be carried out which can provide key insights into different aspects of green HRM implementation. It would be useful to develop a green HRM index to quantitatively capture various features of green HRM. Future research efforts in this area should focus on extending the study sample to include a more diverse array of companies covering a broader range of activities.

\section{References}

CROSBIE, L. - KNIGHT, K. 1995. Strategy for Sustainable Business: Environmental Opportunity and Strategic Choice. Maidenhead, England : McGraw-Hill, 1995.

DITZ, D. R. - BANKS, R. D. 1995. Green Ledgers: Case Studies in Corporate Environmental Accounting. Washington: World Resource Institute, 1995.

JAIN, A. 2016. Green Human Resource Management: Concept in Indian Industries - Present Scenario. In International Journal of Multidisciplinary Allied Research Review and Practices, 2016.

MANDIP, G. 2012. Green HRM: People Management Commitment to Environmental Sustainability. In Research Journal of Recent Sciences, 2012.

MARTHA, S. - ADHIKARI, S. 2013. Green HRM and Sustainability of Ongoing Research in Management \& IT. In International E-journal of Ongoing Research in Management and IT, 2013.

MATHAPATI, C. M. 2013. Green HRM: A Strategic Facet. In Tactful Management Research Journal, 2013.

NORTH, K. 1997. Environmental Business Management. An Introduction, $2^{\text {nd }}$ ed., Geneva : International Labour Office, 1997.

OPATHA, H. - ANTON, A. 2014. Green Human Resource Management: A Simplified General Reflection. In International Business Research, 2014.

RENWICK, D. W. - REDMAN, T. - MAGUIRE, S. 2013. Green HRM: A Review and Research Agenda. In International Journal of Management Review, 2013.

RENWICK, D. W. - REDMAN, T. - MAGUIRE, S. 2012. Green HRM: A Review, Process, Model and Research Agenda. In International Journal of Management Review, 2012.

REVILL, C. 2000. The 'Greening' of Personnel/Human Resource Management: An Assessment. In International Journal of Applied HRM, 2000.

WEHERMEYER, W. 1996. Greening People: Human Resources and Environmental Management. Sheffield: Greenleaf, 1996.

\section{Contact address}

Arpita Kaul, University of Delhi, Sri Venkateswara College, Department of Commerce, Delhi 110021, India 